\author{
Sergey KAPTALAN \\ PhD in Economics, Lecturer of Enterprise Economics and Business Organization Department, \\ Odessa National Economic University, Ukraine, e-mail: tatfru@gmail.com, \\ ORCID ID: https://orcid.org/0000-0002-0298-9524
}

\title{
SYSTEMATIZATION OF AGRO-INDUSTRIAL FORMATIONS TYPES ACCORDING TO VARIOUS CLASSIFICATION FEATURES
}

Kaptalan, S. (2019). Systematization of agro-industrial formations types according to various classification features. Ed.: M. Zvieriakov (ed.-in-ch.) and others [Systematyzatsiia vydiv ahropromyslovykh formuvan za riznymy klasyfikatsiinymy oznakamy; za red.: M. I. Zvieriakova (gol. red.) ta in.], Socio-economic research bulletin; Vìsnik socìal'no-ekonomìčnih doslìdžen' (ISSN 2313-4569), Odessa National Economic University, Odessa, No. 2-3 (70-71), pp. 208-218.

\begin{abstract}
The article provides a critical analysis and systematizes modern approaches to the definition of "agroindustrial formations". So, on the basis of the analysis and genesis of concepts, under agro-industrial formation it is offered to understand set technologically, economically, legally and organizationally connected enterprises and the organizations which are carrying out: providing with resources, production, transportation, storage, processing, marketing and sale of agricultural and agro-industrial production. Following consideration of the historic causes and preconditions of occurrence and development of integration processes in the agricultural sector of the economy, based on the determination of the content of the agricultural sector as a sector of the economy, examines the nature and basic specific features of economic activity of enterprises of agro-industrial sector. Theoretical aspects of economic integration of agro-industrial enterprises are analyzed. Under the integration of enterprises of the agro-industrial complex, it is proposed to understand the process of their unification, deepening of interaction, and such a state of enterprises that provides manageability, integrity, orderliness of their functioning. According to the type of integration processes of agro-industrial formations, it is proposed to distinguish three types of integration into the agro-industrial complex: horizontal, vertical and diversified integration. The essence, as well as positive and negative consequences of each type of integration into the agro-industrial complex are determined. The main positive effect of economic integration is the effect of increasing the scale of activities, as well as the synergistic effect of the unification of economic entities. Also, as a result of consideration of the main theoretical approaches to the classification of AIF, it was systematized representation of scientists about the types of AIF on other various classification features, namely: form of ownership; territorial coverage; industry affiliation; size; method of management; degree of legal independence of subjects; level of economic independence; organizational and legal forms. The classification allows to organize information about agro-industrial formations and is the basis for the development of a systematic idea of the nature of integration in the modern agro-industrial complex.
\end{abstract}

Keywords: agro-industrial formations; integration; agro-industrial complex.

\section{Сергій Михайлович КАПТАЛАН}

кандидат економічних наук, викладач кафедри економіки підприємства та організації підприємницької діяльності, Одеський наџіональний економічний університет, Украйна, e-mail: tatfru@gmail.com, ORCID ID: https://orcid.org/0000-0002-0298-9524

\section{СИСТЕМАТИЗАЦІЯ ВИДІВ АГРОПРОМИСЛОВИХ ФОРМУВАНЬ ЗА РІЗНИМИ КЛАСИФІКАЦЙНИМИ ОЗНАКАМИ}

Капталан С. М. Систематизація видів агропромислових формувань за різними класифікаційними ознаками. Вісник соціально-економічних досліджень : зб. наук. праць / За ред. М. І. Звєрякова (голов. ред.) та ін. Одеса : Одеський національний економічний університет. 2019. № 2-3 (70-71). С. 208-218.

\begin{abstract}
Анотація. У статті здійснено критичний аналіз та систематизовано сучасні підходи до визначення поняття «агропромислові формування». Так, на основі аналізу та генезису понять, під агропромисловим формуванням запропоновано розуміти сукупність технологічно, економічно, юридично й організаційно пов'язаних підприємств та організацій, щзо здійснюють: забезпечення ресурсами, виробництво, транспортування, зберігання, переробку, маркетинг та збут сільськогосподарської та агропромислової продукиії. За підсумками розгляду історичних першопричин та передумов виникнення $i$ розвитку інтеграційних процесів в агропромисловому секторі економіки, на основі визначення змісту АПК як сектору економіки, проаналізовано сутність та основні специфічні риси економічної діяльності підприємств цієї галузі. Проаналізовано теоретичні аспекти економічної інтеграчії підприємств АПК. Під інтеграцією підприємств АПК
\end{abstract}


запропоновано розуміти процес їх об'єднання, поглиблення взаємодї, та такий стан підприємств, щзо забезпечує керованість, иілісність, впорядкованість їх функиіонування. За видом інтеграційних процесів агропромислових формувань, запропоновано виділення трьох видів інтеграції в АПК: горизонтальної, вертикальної та диверсифікованої інтеграції. Визначено сутність, а також позитивні й негативні наслідки кожного з видів інтеграції в АПК. Головним позитивним наслідком економічної інтеграції є ефект збільшення масштабів діяльності, а також синергетичний ефект від об'єднання суб'єктів економічної діяльності. Також, у результаті розгляду основних теоретичних підходів до класифікації АПФ, було систематизовано уявлення науковців про види АПФ за іншими різними класифікаційними ознаками, а саме за: формою власності; територіальним охопленням; галузевою приналежністю; розміром; способом здійснення управління; ступенем юридичної самостійності суб'єктів; рівнем економічної самостійності; організаційно-правовими формами. Проведена класифікація дозволяє впорядкувати інформацію про агропромислові формування та є основою для розробки систематизованого уявлення про характер інтеграчії в сучасному АПК.

Ключові слова: агропромислові формування; інтеграція; агропромисловий комплекс.

\title{
Сергей Михайлович КАПТАЛАН
}

кандидат экономических наук, преподаватель кафедры экономики предприятия и организаџии предпринимательской деятельности, Одесский национальный экономический университет, Украина, e-mail: tatfru@gmail.com, ORCID ID: https://orcid.org/0000-0002-0298-9524

\section{СИСТЕМАТИЗАЦИЯ ВИДОВ АГРОПРОМЫШЛЕННЫХ ФОРМИРОВАНИЙ ПО РАЗЛИЧНЫМ КЛАССИФИКАЦИОННЫМ ПРИЗНАКАМ}

Капталан С. М. Систематизация видов агропромышленных формирований по различным классификащионнылм признакам. Вестник социально-экономических исследований : сб. науч. трудов / Под ред. М. И. Зверякова (глав. ред.) и др. Одесса : Одесский национальный экономический университет. 2019. № 2-3 (70-71). С. $208-218$.

\begin{abstract}
Аннотация. В статье выполнен критический анализ и систематизированы современные подходы к определению понятия «агропромышленные формирования». Так, на основе анализа и генезиса понятий, под агропромылиенным формированием предложено понимать совокупность технологически, экономически, юридически и организациионо связанных предприятий и организациий, осуществляюших: обеспечение ресурсами, производство, транспортировку, хранение, переработку, маркетинг и сбыт сельскохозяйственной и агропромышленной продукиии. По итогам рассмотрения исторических первопричин и предпосылок возникновения и развития интеграџионных процессов в агропромышленном секторе экономики, на основе определения содержания АПК как сектора экономики, проанализированы сущчность и основные специфические черты экономической деятельности предприятий этой отрасли. Проанализировань теоретические аспекть экономической интеграции предприятий АПК. Под интеграцией предприятий АПК предложено понимать процесс их объединение, углубление взаимодействия, и такое состояние предприятий, что обеспечивает управляемость, целостность, упорядоченность их функционирования. По видам интеграџионных процессов агропромышленных формирований, предложено вылеление трех видов интеграџии в АПК: горизонтальной, вертикальной и диверсифицированной интеграции. Определены сущность, а также положительные и отрицательные последствия каждого из видов интеграции в АПК. Главным положстельным следствием экономической интеграции является эффект увеличения масштабов деятельности, а такэе синергетический эффект от объединения субъектов экономической деятельности. Также, в результате рассмотрения основных теоретических подходов к классификации АПФ, было систематизировано представление ученых о видах АПФ по другим различным классификачионным признакам, а именно по: форме собственности; территориальному охвату; отраслевой принадлежности; размеру; способу осуществления управления; степени юридической самостоятельности субъектов; уровню экономической самостоятельности; организационно-правовым формам. Проведенная классификация позволяет упорядочить информацию об агропромышленных формированиях и является основой для разработки систематизированного представления о характере интеграџии в современном АПК.
\end{abstract}

Ключевые слова: агропромышленные формирования; интеграция; агропромышленный комплекс.

JEL classification: D610; O180; Q010; Q130

DOI: https://doi.org/10.33987/vsed.2-3(70-71).2019.208-218

\section{Introduction}

In the process of managing of the enterprise activity, including the management of foreign economic activity, the fundamental organizational component is the definition of certain 
classification characteristics by which the agro-industrial formation can be attributed to one or another type. That is, the effectiveness of management of foreign economic activity largely depends not so much on the economic components, namely, in what form, size, industries, etc. created and operates a specific agro-industrial formation. Global changes in the $21^{\text {st }}$ century in the economy of Ukraine have become the engine of restructuring of agricultural and industrial enterprises, in terms of redistribution of property in the direction of interregional corporate associations, corporations, holdings and other types of associations. As a result of spontaneous and uncontrolled restructuring, most of the capital and agricultural production concentrated in the same hands, in the form of large agro-industrial formations. A significant part of these formations, which are not typical for the domestic experience of agro-industrial integration, have significant differences among themselves and do not have a generalized definition, therefore, there is a need to systematize the types of agroindustrial formations according to various classification criteria.

\section{Aim and methodology of research}

The purpose of the article is to characterize agro-industrial formations in Ukraine in modern conditions of activity, and to determine their types by the main organizational and economic classification characteristics. During the research, methods of tabular ad graphical representation of se research results, logical generalization comparative analysis and system approach, taking into account the dynamic functional dependence between the state of the whole, development and the balance of its constituent element, were used.

\section{Literature review, shortcomings and problem statement}

In the modern scientific literature the problem of transformation relations in the agro-industrial complex of creation and activity of agro-industrial formations is considered in the studies of many Ukrainian and foreign scientists, such as: I. I. lukinova, A. I. Altukhova, V. R. Boeva, I. N. Buzdalov, I. M. Burobkin, P. T. Sabluk, V. M. Tregobchuk, M. A. Khvesik, M. G. Chumachenko, A. S. Lisetsky, P. P. Borshchevsky, B. V. Burkinsky, L. V. Deyneko, O. M. Tsarenko, V. A. Illyashenko, M. I. Horunjy, V. M. Heyets, M. V. Kalinchik, L. E. Cupineci, P. V. Osipov, A. G. Granberg, V .G. Gusakova, O. M. Emelyanova, M. I. Zhukova, S. E. Ilyushonok, O. A. Kalninsh, V. A. Klyukach, Yu. A. Konkina, E. M. Krylatykh, V. I. Kudryashova, V. O. Miloserdova, V. P. Mozhina, M. G. Leshcheva, O. O. Nikonova, A. V. Petrikova, E. E. Rumyantseva, A. B. Soskiev, V. O. Tikhonova, I. G. Usachiova, I. F. Hickova and others.

Today, in Ukraine, both at the state level and at the regional level, the processes of agro-industrial integration, consolidation, creation of new organizations have not yet been regulated in a normative and organizational way. For the functioning of various types of agro-industrial formations in the effective activities of small and medium-sized agribusiness is necessary to create a stable external and internal environment. That is, it is advisable to create and support proportional development of all types of enterprises and units in the agricultural sector, which requires the understanding of basic concepts, their classification features, types and features that characterize the processes. The problem of typification of agro-industrial formations has not yet been developed and has not found legislative approval, although there are many scientific developments in which this concept is classified differently. The issues of analysis and systematization of agro-industrial formations, on the basis of which the system, mechanisms and tools for ensuring food security of the country operate, remain at a very insufficient level of research, which led to the choice of the topic of the article. The lack of conceptual sound public policy in the revival of the domestic agro-industries and food security is the result of insufficient research of the essence and types of agricultural units in conditions of transformation of market economy.

\section{The main material research}

As practice of economic activity of agro-industrial sector in our and other countries of the world shows, the subjects of agro-industrial complex are characterized by multivariance of organizational 
and legal forms $\left[1\right.$, p. 8]. O. Skvortsov at the beginning of the $20^{\text {th }}$ century noted that, the device of land management is determined by the level of economic development of the country and the agricultural sector in particular. According to the changes in economic relations, there should also be changes in the organizational and legal forms of management in the agricultural sector. Such development of forms of agro-industrial enterprises N. Y. Basyurkina suggests calling historicism, and inconsistency, discrepancy of changes of organizational forms to realities of economic relations considers as the reason of decrease in efficiency of their activity [2, p. 5]. This is a reason for more careful consideration of the classification of AIF on various classification features and analysis of the positive and negative aspects of their individual species.

From the beginning it is necessary to determine the essence of the concept of AIF. O. O. Tomilin defines AIF as a community based on the Association of economic entities that are owners of land, property and Finance [3, p. 155]. This definition does not disclose all the features of APF in contrast to the following definition, which was given by V. H. Davletkhanova: AIF is a set of technologically, economically and organizationally related agricultural and industrial enterprises and organizations engaged in the production, storage, processing and bringing to the consumer products from agricultural raw materials. The only thing that in our opinion should be added to this definition is the possibility of including in the AIF enterprises that provide agricultural enterprises with the means of production and financial resources engaged in the transportation of products.

Thus, AIF is proposed to be understood as a set of technologically, economically, legally and organizationally related enterprises and organizations engaged in: provision of resources, production, transportation, storage, processing, marketing and marketing of agricultural and agroindustrial products.

The primary organizational form of management in rural areas is individual agricultural activity, or farming, which is the economic basis for the development of other forms of organization of activities, and is the basis for the formation of the middle class in rural areas, providing employment for residents [4, p. 12]. The next stage in the development of economic relations in agriculture was the need to consolidate production in order to implement the results of STP. In the USSR, such an Association was carried out artificially in the form of collective farms and cooperatives. The artificiality of the Association consisted in the discrepancy of these forms to the existing character of relations in the countryside. In the 70-80-ies of the last century, began to develop such forms of agro-industrial integration, as inter-farm enterprise, district agro-industrial associations, agro-plants, within which agricultural, servicing and processing enterprises were united. Artificiality and discrepancy to realities of development of production forces of these agro-industrial associations was confirmed by their almost complete disappearance after disintegration of the USSR.

In the process of privatization in Ukraine, agricultural producers (collective agricultural enterprises and farms) were given the opportunity to participate in the preferential denationalization of processing and food enterprises. They received free $51 \%$ of the shares of these enterprises, in proportion to the share of raw materials they supplied to this enterprise during the last five years. However, this path of forced integration has not been successful [5, p. 131]. V. G. Andriychuk believes that the process of development of AIF in Ukraine can be divided into three stages. The first stage was the transformation of collective farms into collective agricultural enterprises, the second stage was the disintegration of collective agricultural enterprises into private farms, and the third stage is the consolidation and capitalization of these farms. O. Rankin complements these stages by the section of the capitalization process into sub stages. At the first stage, at the beginning of the third Millennium, agribusiness began to receive large amounts of capital-very often by accident. At the second stage (2001-2003) - a large proportion of "accidental" agricultural enterprises were forced to complete their activities because of its non-core and unprofitability. And only at the third stage during the next ten years there was a meaningful inflow of capital into the agro-industrial complex [6, p. 176]. 
In the legislation of Ukraine such organizational and legal forms of associations of the enterprises as Association, consortium, concern, Corporation are allocated. However, this is a purely formal legal approach to the allocation of AIF by species. Among scientists there is a wide discussion on the establishment of a list of classification features and specific types of AIF. As a result of the consideration of the approaches of modern scientists, a generalization of the classification of AIF by species was carried out.

Common to all scientists is the AIF classification on the basis of ownership, according to which enterprises are divided into: private (individual and family), collective (cooperative, joint stock company, limited liability company and others), state (municipal, municipal, state) [7, p. 262; $8 ; 9 ; 10]$. Sometimes the enterprises compatible on a form of ownership are allocated. Thus, I. A. Kosach and N. I. Kholyavko believe that public-private partnership is a promising direction for the development of activities in the agro-industrial complex [10, p. 3]. The same idea is supported by C. Gerashchenko, who notes that this form of joint activity is common in the EU, where publicprivate partnership is understood as the transfer of certain powers to the private sector, as well as the risks that accompany investment projects in the agro-industrial complex and other areas of activity.

According to the territorial coverage of the AIF can be divided into those that conduct the main activities at the level of the district, region, state and interstate level $[7 ; 8 ; 9, \mathrm{p} .11]$. At the same time, activities at the interstate level can consist both in the formation of joint ventures and in the implementation of foreign trade activities by domestic enterprises. Under the General AIF it is accepted to understand such organizational structure of the international cooperation which consists in Association of the capital of national and foreign businessmen for the purpose of implementation of joint activity in agro-industrial sector in the long term. Sometimes AIF interstate level of territorial coverage is also called transnational.

On branch accessory allocate: production and sale of agricultural production; production, processing and sale of agro-industrial production; production and sale of means of agricultural production and agroindustrial production; others $[7$, p. $265 ; 8 ; 11$, p. 8]. On this basis, it is possible to distinguish the AIF, which carry out their activities in all areas that are part of the agro-industrial complex, so the classification options can be many. We propose to allocate the AIF by industry affiliation on the basis of determining the industry affiliation of the leading subject of the AIF. That enterprise, which has the greatest size of the capital, has the greatest volumes of production or incomes.

According to the type of integration processes observed in the AIF, it is proposed to allocate: not integrated; horizontally integrated; vertically integrated; diversified integrated [7, p. 267-268; 8; 9, p. 11; 11, p. 8]. As a result of theoretical aspects of economic integration of agricultural enterprises analysis, under the integration of enterprises of the agro-industrial complex is proposed to understand the process of their consolidation, deepening cooperation, and this state of enterprises that provides manageability, integrity, orderliness of their functioning.

Horizontally integrated AIFs are associations of enterprises located at the same level of the production cycle, which could be competitors because they produce similar or identical products.

Vertically integrated agro-industrial complex is an Association of enterprises that take part in the provision of all kinds of resources (from material to financial) and the production of agricultural products, its logistics, processing, production of final products and their sale. Special attention needs to be paid to the provision of financial resources to the AIF. Due to the seasonality of production, agricultural enterprises cannot exist without loans.

Vertically integrated enterprises can also be classified according to the depth of integration depending on how many levels of the chain of interactions in the process of production, processing and sale of agricultural products were involved in the integration process. We can distinguish the following components industry interaction in the process of vertical integration of AIF: the provision of resources (fuel and lubricants, raw material, logistical, financial, and other resources); 
agricultural production (crops, livestock, other agricultural activities); processing of agricultural products; production of agricultural products; transportation of agricultural and agro-industrial products (road transport, river transport, sea transport, rail transport); storage of agricultural and agro-industrial products (elevators, warehouses, refrigerators, other facilities); transshipment units of agricultural and agro-industrial products (from land to river/sea, from river to sea, from road to rail, other transshipment options); marketing and marketing of agricultural and agro-industrial products (Fig. 1).

Thus, a vertically integrated agro-industrial complex can unite 8 sectoral components of the chain of interaction in the process of creating and selling consumer value of agricultural products. That is, the integration itself can be classified into 7 levels depending on how many industry components are combined with the leading, key stage of the AIF. Those AIFs, where all 8 sectoral components of the value chain are combined, belong to the vertically integrated enterprises of the $7^{\text {th }}$ level. Those on which vertical integration is only at the initial stage, which combine only two industry components, belong to the vertically integrated AIF level 1.

The higher the level of vertical integration, the more benefits the AIF receives from it. The authors identify many organizational and economic advantages that can be obtained by vertically integrated AIF [12, p. 18; 13, p. 113; 14, p. 120; 15, p. 196]. The main of which can be identified as follows:

- stabilization, streamlining of organizational and economic relations between the subjects of the AIF, which leads to a decrease in the riskiness of activities and harmonization of the distribution of added value;

- absence of "bottlenecks" in the chain of creation and realization of consumer value of agroindustrial products, which is especially important in conditions of monopolization at some stages of the chain;

- savings on transaction and logistics costs;

- synergies with vertical integration.

The latter type of enzyme according to the type of integration integrated diversified AIF, which are characterized by the Association of agricultural enterprises and enterprises that do not participate in providing any kind of resources and agricultural production, its logistics, processing, production of final products and their marketing.

Let's move on to the next classification feature of the AIF. In size, there are small, medium and large AIF $[6 ; 7 ; 11$, p. 8]. Large AIF s have significant advantages in production and economic activities compared to others. Large AIFs have at their disposal a great opportunity to implement the achievements of the NTP, which leads to the use of more modern tools and objects of labor. Large AIFs according to the law of Economics have a lower level of costs per unit of production. In addition, in the context of the crisis of the judicial system and antitrust regulation, large AIFs can use the volume of their activities to obtain monopoly privileges in the market.

The problem remains the choice of criteria by which to distribute the subjects of agriculture on the types of size. N. Y. Basyurkina proposes to take into account the number of entities that have been integrated in the process of economic activity [7, p. 264]. O. O. Erankin believes that the size of the activity should be characterized by the volume of resources or results of the activity of the AIF [6, p. 177]. However, since AIFs may have different outputs and the resources they use to produce them, size criteria should be developed for individual species by industry. In the food processing industry, size is characterized by market share, production volume, production capacity, volume of contracted raw materials.

According to the author, the key feature in agricultural horizontally integrated AIFs is the area of land use in crop production, and the number of animals-in animal husbandry. Despite the fact that the author aptly noted the importance of allocating criteria for the size of the AIF depending on the industry, in our opinion, it is necessary to more clearly outline the principles of such selection. 
In our opinion, the criterion for allocating an enterprise by size should be chosen depending on the type of integration that is inherent in an individual AIF. In the case of horizontal integration, the size criterion should be chosen indicators that characterize the available resource opportunities, since they are common to individual horizontally integrated agribusiness entities. For example, the area of leased land, livestock, production capacity and others.

For vertically integrated AIFs, the criterion should be chosen depending on the volume of production (sales), the production capacity of the leading or final activity. For example, for a vertically integrated AIF the leading element of which is: the production of sunflower oil - sales volume of oil; poultry - volume sales of meat and eggs; for the grain production - sales of grain. An important feature of this approach is that in vertically integrated APFs, size criteria can be measured in natural units.

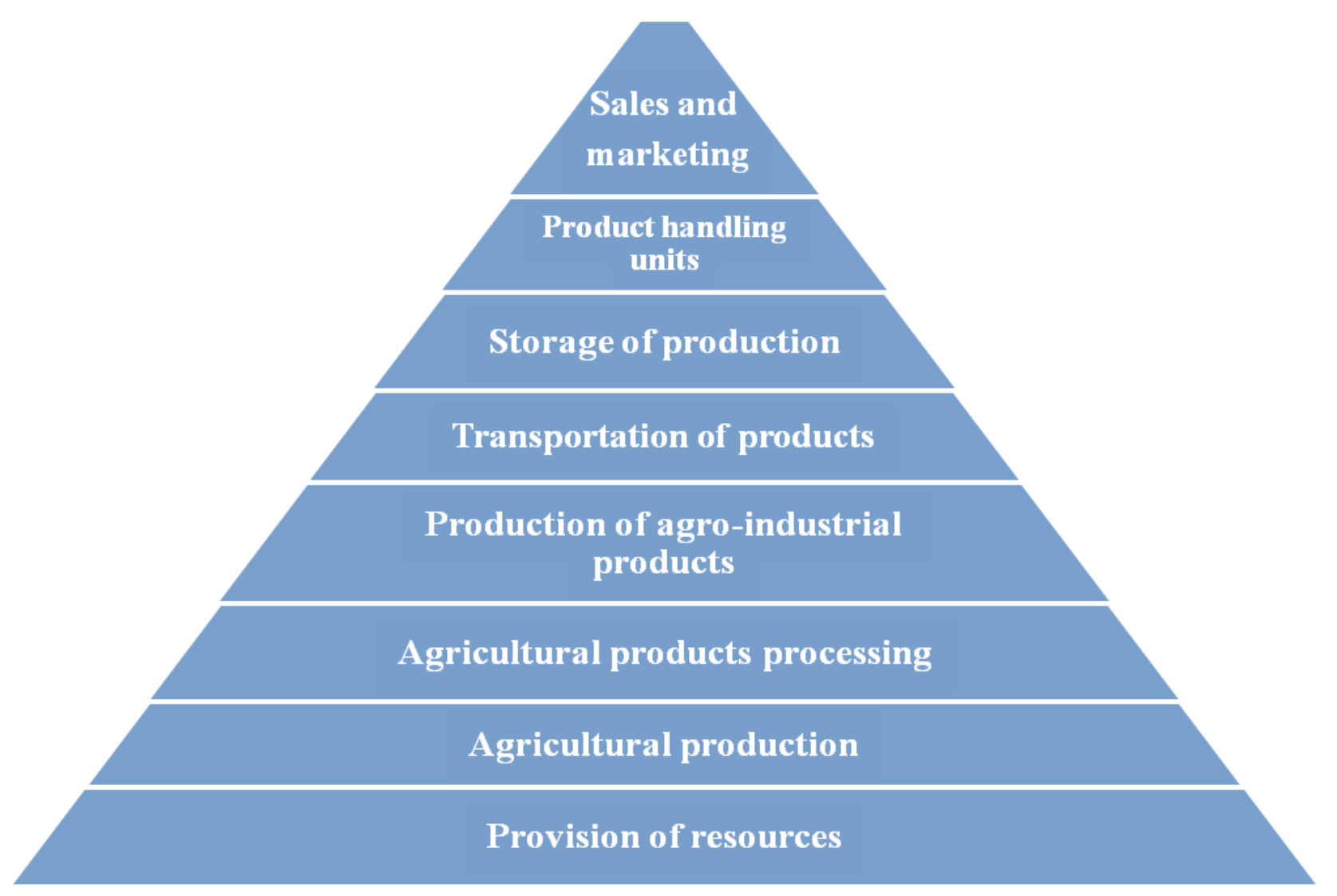

Fig. 1. Sectoral components of interaction in the process of creating and selling consumer value of agricultural products (compiled by the author)

Diversified AIFs are the most difficult to classify by size because they combine enterprises engaged in various activities. Diversified integrated AIFs may not have common production and commercial links. For example, a financial and industrial group that includes a Bank or other financial institution. In diversified AIFs there is no final stage of activity (since there are no such stages as), it is impossible to determine their size by the volume of activity of the leading subject of the AIF, since this will give distorted results (the volume of activity of metallurgical enterprises or banks can not characterize the size of the diversified AIF of which they are part). Therefore, we propose to determine the size of diversified integrated enterprises by the sum of the cost of agricultural products.

According to the method of implementation of management, there are AIF, in which management is carried out on the basis of the organizational apparatus of the leading entity or with the creation of a separate organizational apparatus $[9$, p. $11 ; 7$, p. $266 ; 11$, p. $8 ; 16$, p. 12; 17, p. 61]. Thus, in AIF, which belong to the second type, the functions of ownership and management are divided between legally separate entities. 
Another classification feature is the degree of legal independence of the subjects of the AIF. On this basis, it is possible to distinguish the AIF in which the participants: retained legal independence and is legally different entities; lost legal independence and is part of the parent company $[7$, p. 266-267; 9, p. 11; 11, p. 8]. The loss of legal independence can be complete or partial when a branch of the parent company is created on the basis of an integrated entity.

Legal independence may have different manifestations in terms of economic and managerial independence. According to the level of economic independence, AIF can be divided into those in which the subjects are: almost independent; partially independent and economically independent [7, p. $264 ; 9$, p. $11 ; 11$, p. $8 ; 14$, p. $120 ; 17$, p. $61 ; 18$, p. $132 ; 19$, p. 13]. Legally independent include enterprises that are members of associations, unions and other organizations that unite business entities. Partially independent are the subjects of the AIF, which were formed on the basis of mutual participation in the capital of other subjects of the AIF. Not economically independent can be considered subjects of the AIF, which belong to the so-called holdings, corporations, financial and industrial groups.

Let us consider in more detail the essence and features of holdings in the agro-industrial complex. According to the Law of Ukraine "on holding companies in Ukraine", a holding company is a joint stock company that uses, manages and owns corporate stakes (shares, units) of two or more enterprises. However, the law focuses on the shareholder nature of the relations between the owners of the holding, while in practice there are others. The group of authors refers to the types of corporate associations of those AIF, which are based on the Association of property, namely: cartels, corners, syndicates, trusts, concerns, consortia, financial and industrial groups, conglomerates, holdings, unions, associations, franchisees. We can not agree with the fact that the authors attributed to the associations created on the basis of property associations, cartels, consortia. Therefore we consider, that these AIFs do not provide for the unification of the property of the entities that are part of them.

S. I. Demyanenko considers agricultural holding a specific form of ownership of share capital, which is characterized by the ownership of shares and management of subsidiaries by the parent, which leads to the unification of all enterprises into a single organizational structure with the preservation of economic and legal independence $[20$, p. 51; 56]. The author also focuses only on joint-stock companies, limiting the possibility of considering as holdings of AIF, which are created on the basis of other legal forms, such as companies.

According to E. N. Pugacheva, the agricultural holding is a set of legal entities connected by contractual and property relations for the purpose of management of activity of Association of the enterprises [21]. This definition best reflects the features of this type of AIF, as an agricultural holding.

T. Dudar allocates types of agricultural holdings depending on the directions of the main activity; food agricultural holding, industrial agricultural food holding, commercial agricultural holding, financial agricultural food holding [22, p. 132]. In our opinion, the author tried to combine several classification features in one classification, which only confuses this process. In addition, theoretically, there are many options for combining enterprises of different sectors of the economy into holdings, which makes the classification proposed by the author not complete or unlimited.

Another important issue is the allocation of AIF behind legal forms. At the organizational-legal forms adopted to allocate these types of AIF as a limited liability company, joint stock companies (private, public), cooperatives and those that are under contract and have no legal organizational and legal aspects $[2 ; 7 ; 11$, p. $8 ; 23]$.

Another debatable theoretical and practical issue is the choice of organizational and legal form for the AIF. According to N. Y. Basyurkina this choice depends on the economic feasibility and interests of specific investors-integrators [7, p. 264]. The most common organizational forms are societies, since cooperatives have a small mutual Fund, can not accept business entities that are legal entities. In cooperatives there is no opportunity to receive large loans due to the lack of 
collateral base, which virtually excludes large-scale production $[2, \mathrm{p} .6 ; 33]$. That is why the most widespread integrated AIF with the legal form of the company, namely, public and private joint stock companies and limited liability companies. Another type of society-full society-in our conditions is almost not used, because the full society does not distinguish between the responsibility of the participants of the society for its debts.

Thus, the main dilemma when choosing the legal form of the AIF is the choice between a joint stock company and a limited liability company (hereinafter LLC). In a joint-stock company, the exit of a participant (owner of shares) is free, and does not provide for compensation for the value of shares by the company, as in LLC. On the other hand LLC is a more flexible and less responsible form. In LLC there is no responsibility on debts of AIF, there is no established mechanism of purchase and sale of shares, regulation of meeting. Thus, we agree with the authors who argue that the form of LLC is more promising for a legal organization $[2, \mathrm{p} .6]$.

In addition, some authors on the complexity of the organizational and legal structure suggest to distinguish simple and complex AIF [2, pp. 265-266]. Simple integrated AIFs consist of entities of the same legal form-CJSC, JSC or LLC. While complex structures include entities with different organizational and legal forms. However, we believe that the complexity of the organizational and legal structure primarily depends on the organization of its management, and not on the homogeneity of their composition according to the selected organizational and legal forms.

In addition to the above classification features of AIF species, scientists distinguish others. But as a result of consideration of their essence, it was concluded that other classification features are either not essential, or can be included as part of the above (tab. 1).

Thus, having considered the main theoretical approaches to the classification of AIF, it was concluded that they can be divided into 9 main classification features, namely: form of ownership; territorial coverage; industry affiliation; type of integration processes; size; method of management; degree of legal independence of subjects; level of economic independence; organizational and legal forms.

Table 1

Classification of agro-industrial formations by types ${ }^{1}$

\begin{tabular}{|c|c|}
\hline Classification feature & Types of agro-industrial formations \\
\hline 1. By ownership & $\begin{array}{l}\text { 1) private (single and family); } \\
\text { 2) collective (cooperative, joint stock company, limited liability company and } \\
\text { others); } \\
\text { 3) state (municipal, state); } \\
\text { 4) general. }\end{array}$ \\
\hline $\begin{array}{l}\text { 2. On the territorial } \\
\text { scope }\end{array}$ & $\begin{array}{l}\text { 1) district; } \\
\text { 2) regional; } \\
\text { 3) national; } \\
\text { 4) transnational. }\end{array}$ \\
\hline $\begin{array}{l}\text { 3. By industry } \\
\text { affiliation }\end{array}$ & $\begin{array}{l}\text { 1) production and sale of agricultural products; } \\
\text { 2) production, processing and sale of agricultural products; } \\
\text { 3) production and sale of agricultural products and agro-industrial products; } \\
\text { 4) other. }\end{array}$ \\
\hline $\begin{array}{l}\text { 4. By type of } \\
\text { integration processes }\end{array}$ & $\begin{array}{l}\text { 1) horizontally integrated; } \\
\text { 2) vertically integrated; } \\
\text { 3) diversified integrated. }\end{array}$ \\
\hline 5. In size & $\begin{array}{l}\text { 1) small; } \\
\text { 2) average; } \\
\text { 3) big. }\end{array}$ \\
\hline $\begin{array}{l}\text { 6. According to the } \\
\text { method of } \\
\text { implementation of } \\
\text { management }\end{array}$ & $\begin{array}{l}\text { 1) management is carried out on the organizational basis of the leading entity; } \\
\text { 2) management is carried out with the creation of a separate organizational } \\
\text { apparatus. }\end{array}$ \\
\hline
\end{tabular}




\begin{tabular}{|l|l|}
\hline $\begin{array}{l}\text { 7. According to the } \\
\text { degree of legal } \\
\text { independence }\end{array}$ & $\begin{array}{l}\text { 1) retained legal independence; } \\
\text { 2) lost legal independence. }\end{array}$ \\
\hline $\begin{array}{l}\text { 8. By the level of } \\
\text { economic independence }\end{array}$ & $\begin{array}{l}\text { 1) almost independent; } \\
\text { 2) partially independent; } \\
\text { 3) nonspacing. }\end{array}$ \\
\hline $\begin{array}{l}\text { 9. By organizational } \\
\text { and legal forms }\end{array}$ & $\begin{array}{l}\text { 1) limited liability companies and full companies; } \\
\text { 2) joint stock companies (private, public); } \\
\text { 3) cooperatives; } \\
\text { 4) associations operating on the basis of contracts and do not have } \\
\text { organizational and legal registration. }\end{array}$ \\
\hline
\end{tabular}

${ }^{1}$ Compiled by the author from sources $[1 ; 2 ; 6 ; 7 ; 8 ; 9 ; 10 ; 11 ; 14 ; 16 ; 17 ; 18 ; 19 ; 21 ; 23 ;]$

\section{Research results}

As a result of critical consideration of approaches of the leading domestic and foreign authors to definition of the list of classification signs of division of AIF on types the author's vision according to which nine main classification signs with allocation from two to four types of AIF on each of them were allocated was formed and proved. Also, the organizational and economic advantages in the activities of some of the types of AIF were considered, which allowed to come to conclusions about the economic feasibility of their application in the practical activities of business entities.

\section{Conclusions}

As a result of analysis and systematization of agro-industrial groups, we can identify those organizational, legal, territorial, integration and management characteristics of AIF, which are essential for the formation of organizational-economic management of foreign economic activity of AIF. Further research should focus on the theoretical issues of the relationship and the impact of integration processes on specific types of AIF, as well as the analysis of methodological approaches to assess the level of horizontal and vertical integration of AIF.

\section{References}

1. Yurchyshyn, V. (2002). Scientific and methodological bases of a new stage development of agrarian relations and village social problems solution [Naukovo-metodolohichni zasady rozvytku novoho etapu ahrarnykh vidnosyn i vyrishennia sotsialnykh problem sela], Kompleksnyi rozvytok silskoi mistsevosti Kyiv, s. 7-15 [in Ukrainian]

2. Basyurkina, N. I. (2013). Methodological bases of organizational and legal forms research in largescale agroindustrial production [Metodolohochni zasady doslidzhennia orhanizatsiino-pravovykh form u velykotovarnomu ahropromyslovomu vyrobnytsvi], Ekonomika kharchovoi promyslovosti, No. 1, s. 5-9 [in Ukrainian]

3. Tomilin, O. O. (2013). Industrial relations development in agroindustrial complex as a main element of inter-sectoral relations [Rozvytok vyrobnychykh zviazkiv $\mathrm{v}$ ahropromyslovomu kompleksi yak osnovnoi lanky mizhhaluzevykh vidnosyn], Mechanism of economic regulation, No. 1, s. 149-159 [in Ukrainian]

4. Luzan, Yu. Ya. (2011). Organizational and economic ensuring mechanism of agro-industrial production development of Ukraine: theoretical and methodological aspect [Orhanizatiino-ekonomichnyi mekhanizm zabezpechenia rozvytku ahropromyslovoho vyrobnytstva Ukrainy: theoretykomethodolohichnyi aspekt], No. 2, s. 3-12 [in Ukrainian]

5. Gamma, T. N. et al. (2014). Integration processes development of food industry enterprises of Ukraine [Razvitie integratsionnykh protsessov predpriyatiya pishchevoy promyshlennosti Ukrainy], Biznes inform, No. 4, s. 130-135 [in Russian]

6. Yerankin, O. O. (2008). Formation of agroindustrial formations in Ukraine: globalization and marketing aspect [Formuvannia ahropromyslovykh formuvan], Vcheni zapysky: zb. nauk. prats DVNZ «Kyivskyi natsionalnyi ekonomichnyi universytet im. Vadyma Hetmana», Kyiv, Vol. 10, s. 175-186 [in Ukrainian]

7. Basyurkina, N. I. (2012). Classification features and types of agroindustrial formations in Ukraine [Klasyfikatsiini oznaky i vydy ahropromyslovykh formuvan v Ukraini], Vìsnik socìal'no-ekonomicnih doslìdžen', No. 4 (47), s. 260-269 [in Ukrainian] 
8. Drozdov, A. V. (2001). Theory and methodology of integrated structures formation in agrofood complex: dissertation [Teoriya i metodologiya formirovaniya integrirovannykh struktur $\mathrm{v}$ agroprodovolstvennom komplekse: dissertatsiya d-ra ekon. nauk], Saratov, 321 s. [in Russian]

9. Shilova, N. P. (2013). Organizational and economic development aspects of integrated agroindustrial formations: monograph [Organizatsionno-ekonomicheskie aspekty razvitiya integrirovannykh agropromyshlennykh formirovaniy: monografiya], FGBOU VPO Voronezhskiy GAU, Voronezh, 26 s. [in Russian]

10. Kosach I., Kholyavko N. (2016). The strategy for the development of public-private partnerships in agriculture in the context of food security, Innovative solutions in modern science, Vol. 1, No. 1, available at: https://naukajournal.org/index.php/ISMSD/article/view/715.

11. Klyuchnik, V. I. (2007). Effective development of entrepreneurial activity in agricultural sector of regional economy: dissertation abstract [Efektyvnyi rozvytok pidpryiemnytskoi diialinosti $\mathrm{v}$ ahrarnomu sektori ekonomiky rehionu: avtoreferat dysertatsii kand. ekon. nauk], Mykolaiv, 22 s. [in Ukrainian]

12. Basyurkina, N. I. (2012). Methodological bases of agroindustrial integration [Metodolohichni osnovy ahropromyslovoi intehratsii], Vìsnik socìal'no-ekonomičnih doslìdžen', No. 2 (45), s. 17-23 [in Ukrainian]

13. Petryshyna, N. S., Vasylchuk, I. A. (2011). Agroindustrial complex of Ukraine: problems and prospects of development [Ahropromyslovyi kompleks Ukrainy: problemy ta perspektyvy rozvytku], Nauka i ekonomika, No. 2 (22), s. 109-114 [in Ukrainian]

14. Slepneva, L. R., Onkhonov, A. D. (2015). Economic problems of cooperation and integration in agroindustrial complex of the Republic of Buryatiya [Ekonomicheskie problemy kooperatsii i integratsii v APK respubliki Buryatiya], Tavricheskiy nauchnyi obozrevatel, No. 5, s. 119-121 [in Russian]

15. Khirkivskyi, R. (2014). Integrated holding structure in post-crisis period of agroindustrial complex of Ukraine functioning [Intehrovani holdynhovi struktury u postkryzovyi period funktsionuvaniia APK Ukrainy], Visnyk Lvivsikoho natsionalnoho ahrarnoho universitetu. Seriia: Ekonomika APK, No. 21 (1), s. 194-199 [in Ukrainian]

16. Andriychuk, V. G. (2006). Capitalization of agriculture: measuring the scale and assessing the benefits and threats of implementation [Kapitalizatsiia silskoho hospodarstva: vymir masshtabiv ta otsinka perevah i zahroz zdiisnennia], Ekonomika APK, No. 1, s. 9-15 [in Ukrainian]

17. Ilyin, A. V. (2012). Integration mechanism formation of business structures in agricultural sector of the economy [Formirovanie mekhanizma integratsii predprinimatelskikh struktur $\mathrm{v}$ agrarnom sektore ekonomiki], Sotsialino-ekonomicheskie yavleniya i protsessy, No. 2 (62), s. 57-62 [in Russian]

18. Osipov, P. V. (2004). Integrated production potential of food industry [Intehralnyi vyrobnychyi potentsial kharchovoi promyslovosti], Instytut problem rynku i ekonomiko-ekolohichnykh doslidzhen NAN Ukrainy, Odesa, 289 s. [in Ukrainian]

19. Koretska, S. O. (2012). Economic mechanism of agroindustrial integration development [Ekonomichnyi mekhanizm rozvytku ahropromyslovoi intahratsii], Ahrosvit, No. 7, s. 10-14 [in Ukrainian]

20. Demyanenko, S. (2009). Agroholdings in Ukraine: formation and development processf [Ahrokholdynhy v Ukraini: protses stanovlennia i rozvytku], Ekonomika Ukrainy, No. 12 (569), s. 50-59 [in Ukrainian]

21. Pugacheva, E. N. (2001). Investment attractiveness of agricultural enterprises [Investitsionnaya privlekatelnost agrarnykh predpriyatiy], DonNU, Donetsk, 216 s. [in Russian]

22. Dudar, T. (2012). Problems of vertically integrated structures formation and development in agriculture [Problemy formuvannia ta rozvytku vertykalno intehrovanykh struktur u silskomu hospodarstvi], Visnyk TNEU, No. 1, s. 126-137 [in Ukrainian]

23. Leshcheva, M. G., Trukhachev, V. I. (2008). Integration processes development in agricultural sector of the economy [Razvitie integratsionnykh protsessov v agrarnoy sfere ekonomiki], AGRUS, Stavropol, $126 \mathrm{~s}$. [in Russian] 